\title{
Evaluation of markers CD4+, CD8+, IFN- $\gamma$ in male smokers in diayla governorate / Iraq
}

\author{
Sarah Raad Ismail (Msc) $)^{1}$, Abbas Abod Farhan $(\mathrm{PhD})^{2}$ and Mohmmed Abdul Daim
}

Saleh $(\mathrm{PhD})^{3}$

\begin{abstract}
Background: Cigarette smoking habit is widely distribute in the whole world, obviously this bad habit responsible on many diseases which affect the general personal health of the smokers through its effect on the organs of the body in general and the immune system in particular.

Objective:To determination of the smoking effect on some immunity parameters and compare the results with the non-smokers by using IFN- $\gamma$, CD4+and CD8+.

Patients and Methods: 45 of smokers blood samples and 44 of non-smokers blood samples are collected. The levels of cellular of IFN- $\gamma, \mathrm{CD} 4+$ and $\mathrm{CD} 8+$ has been determined by using sandwich ELISA test.

Results: The study included 45 smoker that have the average age of $29.60( \pm) 10.36$ year, while the healthy non-smokers group have 44 person who's have the average age of $26.56( \pm)$ 9.09 years old. When comparing the level of CD4+T cells ,CD8+T and the level of IFN- $\gamma$ with the number of cigarettes consumed per day, the class (20-1) was found to be the highest average of T cells.while (40-21) were less than average, with no significant difference. When comparing the level of CD4+T cells and the level of CD8+T cells with IFN- $\gamma$ with smoking duration, the highest mean T-cell (10-6) years and the lowest mean (25-21). The results of the present study showed a statistically significant association between CD4+, CD8+and IFN- $\gamma$ molecules.

Conclusion: The general results of the tests on the effect of smoking on immunologic markers CD4+, CD8+and IFN-yassumed an increase in the ratio of the three indicators compared to the control group.
\end{abstract}

Keywords: Smoking, Cytokines, ELISA (enzyme-linked immunoabsorbent assay).

Corresponding Author: sarahraad888@gmail.com

Received: $15^{\text {th }}$ July 2018

Accepted: $31^{\text {th }}$ July 2018

https://doi.org/10.26505/DJM

${ }^{1,2}$ Biology Department- College of Education for Pure Sciences- University of Diyala -Diyala- Iraq. ${ }^{3}$ Biotechnology Department -College of science -University of Diyala- Diyala-Iraq.

\section{Introduction}

Smoking is a process in which tobacco is burned and tasted. more than 5 million people killed annually by smoking[1]. Smoking is an important risk factor for several diseases such as atherosclerosis , cardiovascular disease and about $36 \%$ of the population is at risk of myocardial infarction due to smoking[2]. It is widely known that smokers have a risk of cardiovascular disease, high blood pressure, heart attack, thrombosis and COPD( chronic obstructive pulmonary disease[3]. As time passes, smok precepts a large amounts of carcinogenic substances in the mouth, throat and lungs. 
WHO estimates that between 2000 and 2025, the number of smokers will rise from about 1.2 billion to 1.7 billion . currently the estimated number of mortality is 6 million around the world will double The next 20 years, with many of these premature deaths, are also estimated at about 600,000 people. Also The effects of second-hand smoke is associated with poor health, disability and death from noncommunicable chronic diseases, are associated with increased risk of death The Resulting from communicable diseases[4]. Co-Smoking diseases is the second most popular diseases after hypertension[5]. Cigarette smoking affects the immune response mediated by cells and antibodies[6]. Cigarette smoke contains strong inhibitors such as nicotine, catechol and hydroquinone to produce cellular cytokines such as IL-1B, IL- 2 , IFN- $\gamma$,TNF$\alpha$ in humans, which partially explain the lower level of MCP-1 in smokers compared with nonsmokers[7]. the immunity principle is fighting the infections, foreign and cancer cells[8]. Studies show that there is an increase in the number of white leukocytes (considered the first line of defense against microbial infections) but there was a decrease in the effectiveness of neutrophils With reduce of chemical attraction and adhesion And has the ability to produce cellular motility, which proved that smoking affects the number of lymphocytes and production of antibodies and increase levels of CD3+ and CD4+[9].

\section{Patients and Methods}

The study was done for the period from $1 / 9 / 2017$ to $1 / 5 / 2018$ in Diyala governorate. 45 samples of the blood of male smokers have been collected and 44 samples of male non-smokers, were used as a control group. They were not suffering from any chronic or severe disease according to the questionnaire. The blood was drawn in the test tubes and left for 30 minutes at room temperature for coagulation. The serum was then separated by a centrifuge for 5 minutes and at a rate of $5000 \mathrm{rpm}$. The serum was divided into equal amounts $(250 \mu \mathrm{l})$ in small tubes (Eppendorff) and stored at (¿̊-20) temperature until use. Each section of the serum was used once to avoid repeated melting and freezing of the model.

Principle and method of work 1-Determine the level, IFN- $\gamma$, CD4+, CD8+ in the serum

\section{A-Principle of test work}

This test uses a quantity of ready-made enzymes and immuno-assay technique, where the adsorbent assay of the Sandwich ELISA test was used to estimate the level of CD4+. CD4+ was added to the previously labeled monoclonal antibodies for CD4+ After incubation, anti-CD4+ antibodies with biotin were added to the streptavidin-HRP, which leads to the formation of the immune complex. After the incubation process, the unrelated enzymes were removed and the dish was washed and the base material $A$ and $B$ were added and the solution was then transformed from color Blue to yellow with warm impact, The absorption of solutions and the absorption of samples were 
calculated then calculate the concentration of samples for to CD4+ [10].

The same principle applies to the other indicators measured in this study, IFN- $\gamma$ and CD8+ cell molecules, through which $\mathrm{T}$ cytotoxic cells can be inferred by biotin and the rest of the materials processed with each diagnostic kit.

\section{B. Method of work \\ CD4+, CD8+, IFN- $\gamma$ Procedure}

\section{Preparation of standard solutions}

The CD4+ solution, which is equipped with the diagnostic kit, was diluted by a series of dilutions of (5) with concentration (19ng/L, $9.5 \mathrm{ng} / \mathrm{L}, 4.75 \mathrm{ng} / \mathrm{L}, 2.375 \mathrm{ng} / \mathrm{L}, 1.1857 \mathrm{ng} / \mathrm{L})$ respectively.

A dilution of the CD8+ solution, equipped with the diagnostic kit, was performed through a(5) with concentration (36ng/L, $18 \mathrm{ng} / \mathrm{L}, \quad 95 \mathrm{ng} / \mathrm{L}, \quad 4.5 \mathrm{ng} / \mathrm{L}, \quad 2.25 \mathrm{ng} / \mathrm{L})$ respectively.

The IFN- $\gamma$ solution, which is equipped with the diagnostic kit, was diluted by a (5) with concentration $\quad(240 \mathrm{ng} / \mathrm{L}, 120 \mathrm{ng} / \mathrm{L}, 60 \mathrm{ng} / \mathrm{L}$, $30 \mathrm{ng} / \mathrm{L}, 15 \mathrm{ng} / \mathrm{L}$ ) respectively.

\section{2-Addition of samples}

The standard solutions and samples has been prepared according to the instructions.

\section{3-Preparation of the washing solution}

Concentrate the $30 \mathrm{x}$ wash solution with the distilled water that we need later.

\section{Washing phase}

The lid was carefully raised at this stage for the purpose of removing all that is stuck on the surface of the tubes was washed all the tubes with the solution of washing and the washing process was repeated 5 times between each one and 30 seconds.

\section{4-Color development}

First, add the Chromogen reagent $\mathrm{A}$ to the all tubes by 50 microliters. After adding 50 microliters from the Chromogen reagent $\mathrm{B}$ for each tube, the tubes are shake gently together and cover the plate equipped with the diagnostic kit and then put in incubator at $37^{\circ} \mathrm{C}$ for 10 minutes away from light. The addition of the conjugate HRP enzyme is directly related to the antibody associated with the antigen in the ELISA dish and the addition of substrate (TMP) latter, as a chemical compound that interacts with the enzyme (HRP), is chemically reacting to the oxidation process with the help of hydrogen peroxide In the substrate (TMP) that leads to release of ammonia group $\mathrm{NH} 2$ electrons in the installation of the HRP)) as a protein of the type alpha and as a result of this interaction is generated blue color.

\section{5-Stop phase}

Add 50 microliters of the stop solution to all the tubes, which is designed to stop the reaction and change the color from blue to yellow and at the same moment.

\section{6-Reading results}

Samples was measured at a wavelength (450 $\mathrm{nm}) \mathrm{nm}$ after 10 minutes of addition of the solution.

\section{Statistical analysis}

Data of current study were analysed by using chi-square to compared between percentages, ( $\mathrm{T}$ test) to compared between two numeric groups (Mean \pm SD), and (F test (ANOVA)) to compared between more than 
two numeric groups (Mean \pm SD), and used ( r) to study correlation relationship between numeric variables, also we used (ROC) to calculate sensitivity and specifity for some parameters. A level of significance of $\alpha=0.05$ was applied to test. (SPSS v.21 and Excel 2013) program used to analyze current data [11].

\section{Results}

Table (1): Distribution of Study Groups by Age.

\begin{tabular}{||c||c||c||c||}
\hline \multicolumn{5}{|c||}{ Age of study groups } \\
\hline \hline Study groups & No & Mean & Std. Deviation \\
\hline \hline Smoking & 45 & 29.6000 & 9.39974 \\
\hline \hline No smoking & 44 & 26.5682 & \\
\hline \hline Total & 89 & & \\
& & & \\
\hline \hline Sig & & & \\
\hline \hline
\end{tabular}

When comparing the level of CD4+ T cells with the number of cigarettes consumed per day, the class (1-20) cigarette was found to be the highest average of T cells (7.19 \pm
The current study included 45 smokers, with an average age of $(29.60 \pm 10.39)$ years and a life span of (15-55) years. The control group includes 44 non-smokers who are apparently healthy with an average age of $26.56 \pm 9.09$ years and a life span of (15-47) years. with no significant difference as in Table (1).
8.03). The two groups $(21-40,40 \leq)$ cigarette were the least common help $\mathrm{T}$ cells The assistance was $(4.27 \pm 1.49,4.82 \pm 0.70)$ respectively, with no significant difference as shown in Table (2).

Table (2): CD4+ ratio of cigarettes consumed per day per group of smokers.

\begin{tabular}{|c|c|c|c|c|}
\hline \multicolumn{2}{|c|}{ Number of cigarette } & $\mathrm{N}$ & Mean & Std. Deviation \\
\hline \multirow[t]{4}{*}{$\mathrm{CD}^{+}$} & $1-20$ & 27 & 7.1963 & 8.03662 \\
\hline & $21-40$ & 15 & 4.2753 & 1.49617 \\
\hline & $>40$ & 3 & 4.8260 & .70230 \\
\hline & Total & 45 & 6.0646 & 6.39389 \\
\hline $\mathrm{F}$ & \multicolumn{4}{|c|}{1.070} \\
\hline Sig & \multicolumn{4}{|c|}{0.352} \\
\hline
\end{tabular}


When comparing the level of citotoxic $\mathrm{T}$ cells with the number of cigarettes consumed per day, the class (1-20) cigarette was found to be the highest average of toxic $\mathrm{T}$ cells $(10.50 \pm 9.86)$, while the groups $(21-40$,
$40 \leq$ ) cigarette were the least common citotoxic $\mathrm{T}$ cells The assistance was $(2.24 \pm$ $48.19,4.68 \pm 7.02$ ) respectively with no significant difference as in Table (3).

Table (3): CD8 + number of cigarettes consumed per day for smokers group.

\begin{tabular}{|c|c|c|c|c|}
\hline \multicolumn{2}{|c|}{ Number of cigarette } & $\mathrm{N}$ & Mean & Std. Deviation \\
\hline \multirow[t]{4}{*}{$\mathrm{CD}^{+}$} & $1-20$ & 27 & 10.5098 & 9.86456 \\
\hline & $21-40$ & 15 & 8.1985 & 2.24084 \\
\hline & $>40$ & 3 & 7.0290 & 4.68455 \\
\hline & Total & 45 & 9.5073 & 7.85594 \\
\hline $\mathrm{F}$ & \multicolumn{4}{|c|}{0.566} \\
\hline Sig & \multicolumn{4}{|c|}{0.572} \\
\hline
\end{tabular}

When comparing the level of IFN- $\gamma$ with the number of cigarettes consumed per day, the class (1-20) cigarette was found to have the highest mean of IFN- $\gamma(88.63 \pm 184.77)$, while the two groups $(21-40,40 \leq)$ cigarettw were the least common IFN- $\gamma$ was $(42.50 \pm$ $11.10,49.41 \pm 4.35)$ respectively, with no significant difference as in Table (4).

Table (4): IFN- $\gamma$ relationship with the number of cigarettes consumed per day for the smokers group.

\begin{tabular}{|c||c|c|c|c|}
\hline \multicolumn{2}{|c|}{ Number of cigarette } & $\mathrm{N}$ & Mean & Std. Deviation \\
\hline \hline \multirow{3}{*}{ IFN- $\gamma$} & $1-20$ & 27 & 88.6306 & 184.77754 \\
\cline { 2 - 5 } & $21-40$ & 15 & 42.5067 & 11.10817 \\
\cline { 2 - 5 } & $>40$ & 3 & 49.4157 & 4.35332 \\
\cline { 2 - 5 } & Total & 45 & 70.6417 & 143.92541 \\
\hline F & \multicolumn{3}{|c}{0.519} \\
\hline Sig & \multicolumn{3}{|c}{0.599} \\
\hline
\end{tabular}

When comparing the level of help T-cells with the length of smoking, the highest mean help T-cell (6-10) years was found to be
$(9.12 \pm 13.28)$ and the lowest in the (21-25) years was found to be $(4.42 \pm 0)$ There is a significant difference as in Table (5). 
Table (5): CD4 + relationship with smoking duration for smokers group.

\begin{tabular}{|c|c|c|c|c|}
\hline & Duration & $\overline{\mathrm{N}}$ & Mean & $\begin{array}{c}\text { Std. } \\
\text { Deviation } \\
\end{array}$ \\
\hline \multirow{7}{*}{$\underset{+}{\text { CD4 }}$} & $1-5$ & 18 & 4.9575 & 1.27114 \\
\hline & $6-10$ & 10 & 9.1231 & 13.28139 \\
\hline & $11-15$ & 6 & 5.7747 & 1.62397 \\
\hline & $16-20$ & 7 & 5.6821 & 2.34634 \\
\hline & $21-25$ & 1 & 4.4210 & \\
\hline & $>25$ & 3 & 4.5320 & 2.30987 \\
\hline & Total & 45 & 6.0646 & 6.39389 \\
\hline $\mathrm{F}$ & \multicolumn{4}{|c|}{0.592} \\
\hline Sig & \multicolumn{4}{|c|}{0.706} \\
\hline
\end{tabular}

When comparing the level of citotoxic $\mathrm{T}$ cells with the duration of smoking, the highest mean citotoxic $\mathrm{T}$ cells (6-10) years, which was $(13.55 \pm 15.36)$ and the lowest in the (21-25) years was found to be $(6.96 \pm 0)$ There is a significant difference as in Table (6).

Table (6): CD8 + relationship with duration of smoking for smokers group.

\begin{tabular}{|c|c|c|c|c|}
\hline & "Duration & 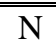 & Mean & S Std. Deviation \\
\hline \multirow[t]{7}{*}{$\mathrm{CD}^{+}$} & $\overline{1-5}$ & $\overline{c 18}$ & $\bar{~} 7.8701$ & 2.63594 \\
\hline & 6-10 & 210 & 13.5525 & $\begin{array}{l}15.36778 \\
\end{array}$ \\
\hline & $111-15$ & 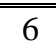 & 9.9363 & 3.35566 \\
\hline & $16-20$ & 7 & 8.7347 & 5.45819 \\
\hline & $21-25$ & 1 & 26.9680 & . \\
\hline & $>25$ & 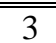 & $\overline{7.6380}$ & 1.16188 \\
\hline & Total & 245 & 9.5073 & 7.85594 \\
\hline $\mathrm{F}$ & \multicolumn{4}{|c|}{0.736} \\
\hline Sig & \multicolumn{4}{|c|}{0.601} \\
\hline
\end{tabular}

When comparing the IFN- $\gamma$ level with the duration of smoking, the highest IFN- $\gamma$ was found in the (6-10) years, which was
(148.55 \pm 302.40$)$ and the lowest in the (2125) years was found to be $(24.24 \pm 0)$ There is a significant difference as in Table (7). 
Table (7): IFN- $\gamma$ relationship with duration of smoking for smokers group.

\begin{tabular}{|c|c|c|c|c|}
\hline & $\begin{array}{l}\text { Duration } \\
\end{array}$ & $\mathrm{N}$ & Mean & Std. Deviation \\
\hline \multirow[t]{7}{*}{ IFN- $\gamma$} & $1-5$ & 18 & 48.0025 & 13.56344 \\
\hline & $6-10$ & 10 & 148.5514 & 302.40885 \\
\hline & $11-15$ & $\overline{c 6}$ & 60.5595 & 29.64213 \\
\hline & $16-20$ & 7 & 44.6016 & 13.17264 \\
\hline & $21-25$ & 1 & 24.2470 & . \\
\hline & $>25$ & 3 & 43.1670 & 7.70872 \\
\hline & Total & 445 & 70.6417 & 143.92541 \\
\hline $\mathrm{F}$ & \multicolumn{4}{|c|}{0.747} \\
\hline Sig & \multicolumn{4}{|c|}{0.593} \\
\hline
\end{tabular}

The results of the present study showed a statistically significant correlation between CD4+ and IFN- $\gamma$ molecules where the correlation coefficient was (0.934) and correlation coefficient between CD4+ molecules and CD8+ molecules (0.901). The results of the present study showed a significant statistical correlation High correlation between $\mathrm{CD} 8+$ and IFN- $\gamma$ molecules where the correlation coefficient was 0.895 and the correlation coefficient between CD8+ and CD4+ molecules was 0.901. The results of the present study showed that the association between IFN- $\gamma$ and the cellular immunity of helper $\mathrm{T}$ cells and $\mathrm{T}$ - A statistically significant correlation was found to be found together The correlation between IFN- $\gamma$ and CD8+ molecules is equal to (0.895) and the correlation coefficient between IFN- $\gamma$ and CD4+ molecules is equal to (0.934) as in Table (8).

Table (8): The correlation between the immunological indicators measured in this study.

\begin{tabular}{|c|c|c|c|c|c|}
\hline & & "age & INF & CD8 & $\bar{~} \mathrm{CD} 4$ \\
\hline \multirow[t]{3}{*}{ age } & $\bar{r}$ & 1 & .064 & .027 & .033 \\
\hline & $\bar{p}$ & & .552 & .803 & .758 \\
\hline & $\mathrm{n}$ & 89 & 89 & 89 & 89 \\
\hline \multirow[t]{3}{*}{ IFN- $\gamma$} & r & .064 & 1 & $.895^{* *}$ & $.934^{* * 4}$ \\
\hline & $\mathrm{p}$ & .552 & & .000 & .000 \\
\hline & $\mathrm{n}$ & 89 & 89 & 89 & 89 \\
\hline \multirow[t]{3}{*}{$\mathrm{CD}^{+}{ }^{+}$} & $\bar{r}$ & $\begin{array}{c}.027 \\
\end{array}$ & $.895^{* *}$ & 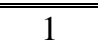 & $.901^{* * x}$ \\
\hline & $\bar{p}$ & ב.803 & (2.000 & & .000 \\
\hline & $\mathrm{n}$ & 89 & 89 & 89 & 89 \\
\hline \multirow[t]{3}{*}{$\mathrm{CD}{ }^{+}$} & $\bar{r}$ & $\begin{array}{c}.033 \\
\end{array}$ & $.934^{* * *}$ & $9901^{* * *}$ & 1 \\
\hline & $p$ & 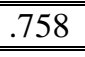 & .000 & ב.000 & \\
\hline & $\mathrm{n}$ & 89 & 89 & 89 & 89 \\
\hline
\end{tabular}




\section{Discussion}

The current study included 45 smokers, with an average age of $(29.60 \pm 10.39)$ years and a life span of [15-55] years. The control group includes 44 non-smokers who are apparently healthy with an average age of $(26.56 \pm 9.09)$ years and a life span of [5-47] years. With no significant difference, many young people between the ages of [12-20] years will start smoking and this category constitutes a large part of the 1.5 million people who start daily smoking each year and as a result, is expected to suffer 5.6 million A child alive today of premature death attributable to cigarette smoking because of their practice of smoking at an early age [12], where the ages [12-17] years is a clear time to develop the concept ([13] The results of this study were consistent with several studies that showed that there were no significant differences $(0.148=\operatorname{sig})$ when comparing the group of smokers with the group of non-smokers by age [14].The results of the current study also coincided with the results of another study conducted by researchers [15] to determine the relationship of smoking with age and showed that there are no significant differences of statistical significance.

When comparing the level of CD4+ T cells with the number of cigarettes consumed per day, the class (1-20) cigarette was found to be the highest average of $\mathrm{T}$ cells $(7.19 \pm$ $8.03)$. The two groups $(21-40,40 \leq)$ cigarette were the least common help $\mathrm{T}$ cells The assistance was $(4.27 \pm 1.49,4.82 \pm 0.70)$ respectively, with no significant difference.
Those who studied the effect of cigarette smoking on T-cell groups reported that current smokers had significantly higher lymphocyte counts than non-smokers, with CD4+ Was significantly higher among smokers than nonsmokers C cells CD4+ tend to increase with the number of cigarettes smoked per day, where the disorder leads in a guest under the influence of the adrenal gland stress factor such as smoke to play an important role in raising the number of lymphocytes [16]. The results of studies showed an increase in the number of CD4+ T cells and their association with the daily smoking rate, where an increase in CD4+ was found in smokers who smoked excessively compared with smokers at a mild to moderate daily rate of smoking [17].Where studies have shown that the decrease in CD4 + cells was significantly associated with the number of cigarettes that are self-smoked per day for each additional cigarettes smoked daily, CD4 cells were kept [18].

When comparing the level of citotoxic $\mathrm{T}$ cells with the number of cigarettes consumed per day, the class (1-20) cigarette was found to be the highest average of toxic $\mathrm{T}$ cells $(10.50 \pm 9.86)$, while the groups (21-40, $40 \leq$ ) cigarette were the least common citotoxic $\mathrm{T}$ cells The assistance was $(2.24 \pm$ $48.19,4.68 \pm 7.02$ ) respectively with no significant difference. Results of studies showed that there was no significant increase in the T-cell level of smokers who smoked excessively than moderately [17]. Studies 
showed that smokers who smoke moderately to a few have an increase in the number of CD4+ and CD8+ T cells, while smokers who smoke excessively have a decrease in CD4+ cells and an increase in cells CD8+ [19].

When comparing the level of IFN- $\gamma$ with the number of cigarettes consumed per day, the class (1-20) cigarette was found to have the highest mean of IFN- $\gamma(88.63 \pm 184.77)$, while the two groups $(21-40,40 \leq)$ cigarettw were the least common IFN- $\gamma$ was $(42.50 \pm$ $11.10,49.41 \pm 4.35$ ) respectively, with no significant difference. Increasing evidence suggests that macrophages and lymphocytes are important stimuli in the chronic inflammation of smoke, which can release active IFN- cells that work As an activation agent for macrophage cells [20].

When comparing the level of help T-cells with the length of smoking, the highest mean help T-cell (6-10) years was found to be (9.12 \pm 13.28$)$ and the lowest in the (21-25) years was found to be $(4.42 \pm 0)$ There is a significant difference The results of the present study were consistent with studies showing an increase in CD4+ and CD8+ in smokers for less than 10 years and then in smokers for more than 10 years. These results are due to weak cellular immunity in smokers during the period of smoking[21].

When comparing the level of citotoxic $\mathrm{T}$ cells with the duration of smoking, the highest mean citotoxic T cells (6-10) years, which was (13.55 \pm 15.36$)$ and the lowest in the (21-25) years was found to be $(6.96 \pm 0)$ There is a significant difference. Some studies have shown that there is a decrease in
CD4+ / CD8+ due to decreased lysozyme concentration, immunoglobulins and a decrease in the number of natural killer cells (CD16+) especially in addicts who smoked more than 10 years and an increase in the number of cytotoxic T lymphocytes (CD8+) [21].

When comparing the IFN- $\gamma$ level with the duration of smoking, the highest IFN- $\gamma$ was found in the (6-10) years, which was (148.55 \pm 302.40$)$ and the lowest in the (21$25)$ years was found to be $(24.24 \pm 0)$ There is a significant difference. It appears that cigarette smoke has multiple effects as it modifies the anti-viral epithelial cells in the airway as well as inhibiting interferon responses. The long-term clinical duration of cigarette smoking with a period of exposure of inflammatory cells to cigarette smoke extract and IFN- $\gamma$ was required to discourage IFN- $\gamma$ induced cell signals where the cigarette smoke extract can indirectly affect IFN- $\gamma$ mediated immunity. There are also many interferon-controlled pathways that control the antiviral defense that can be affected by cigarette smoke extract [22].

The results showed a significant association between $\mathrm{CD} 4+$ and $\mathrm{CD} 8+$ and IFN- $\gamma$ molecules. There is a correlation between cellular immunity among them to achieve the ultimate goal of eliminating the antigen through the reaction of the immune response and the T-Cell cells responsible for cellular immunity, Cellular immunity involves several subgroups of $\mathrm{T}$ lymphocytes, each of which has the specificity of one of the antigen determinants. A different function 
and each $\mathrm{T}$ cell carrying multiple identical antigen receptors called TCR receptor receptors is directly distributed to the antigen site and performs its function towards its interaction With antigen $[23,24]$.

\section{References}

[1]Shah, B.; Nepal, A.; Agrawal, M. \& Sinha, A. The effects of cigarette smoking on hemoglobin levels compared smokers and non-smokers. Sunsari Technical College Journal (2012). 1(1): 2091-2102.

[2]Asthana, A.; Johnson, H.M.; Piper, M.E.; Fiore, M.C.; Baker, T.B. \& Stein, J.H . Effects of smoking intensity and cessation on inflammatory markers in a large cohort of active smokers. American Heart Journal (2010). 160(3): 458-463.

[3] Alhemieri, A. Effect of cigarette smoking on some heamatological and biochemical factors in blood of men with aging. Basrah Journal of Scienec (2008). 26(1): 56-67.

[4]World Health Organisation.(2015). global report on trends in prevalence oftobacco smoking .

[5] Lim, S.S.; Vos, T.; Flaxman, A.; Danaei, G.; Shibuya, K.; Adair-Rohani, H.; et al. A comparative risk assessment of burden of disease and injury attributable to 67 risk factors and risk factor clusters in 21 regions, 1990-2010: a systematic analysis for the Global Burden of Disease Study 2010. Lancet (2012). 380(9859): 2224-2260.

[6]Arnson, Y.; Shoenfeld, Y. \& Amital, H. Effects of tobacco smoke on immunity, inflammation and autoimmunity. Journal Autoimmunity (2010). 34(3):J258-J265.
[7]Wraith, D.C. \& Nicholson, L.B. The adaptive immune system in diseases of the central nervous system. The Journal of Clinical Investigation(2012). 122(4):11721197.

[8]Ouyang, Y.; Virasch, N.; Hao, P.; Aubrey, M.T.; Mukerjee, N.; Bierer, B. E. \& Freed, B. M. Suppression of human IL-1 $\beta$, IL-2, IFN- $\gamma$, and TNF- $\alpha$ production by cigarette smoke extracts. The Journal of Allergy and Clinical Immunology(2000). 106(2): 280287.

[9]Petropoulos, G.; Mckay, I.J. \& Hughes, F.J. The.association between Neutrophil numbers and interleukin -1alpha concentration in gingivalcrevicular fluid of smokers and nonsmokers with periodontal disease. Journal periondontalogy (2004). 31(5):390-395.

[10]Beutler, B.; Greenwald, D. \& Hulmes, J.D. Identity of tumor necrosis factor and the macrophage - secreted factor cachectin. Nature (1985). 316: 552 - 554.

[11]Levsesque, R. SSPS Programming and Data Management ,4th ed .Chicago (2007). pp:522.

[12]Centers for Disease Control and Prevention. The health consequences of smoking - 50 years of progress: A report of the Surgeon General.(2014). Atlanta, GA: Author.

[13]Hertel, A.W. \& Mermelstein, R.J. Smoker identity and smoking escalation among adolescents. Health Psychology (2012). 31(4):467-475.

[14] Alhibrii, M.H.; Abdrabo, A.A. \& Lutfi, M.F. Influence of chronic cigarette smoking 
on serum biochemical profile among Sudanese smoker. Asian Journal of Biomedical and Pharmaceutical Sciences (2013). 3(18): 17-21.

[15] Kayali, S. \& Demir, F. The effects of cigarette smoking on ventricular repolarization in adolescents. Einstein (2017). 15(3):251-5.

[16]Shipa, S.A.; Rana, M.; Miah, F.; Alam, J. \& Mahmud, M.G.R. Effect of Intensity of Cigarette Smoking on Leukocytes among Adult Men and Women Smokers in Bangladesh. Asia Pacific Journal of Medical Toxicology (2017). 6(1):12-17.

[17] Tanigawa, T; Araki, S.; Nakata, A.; Kitamura, F.; Yasumoto, M.; Sakurai, S. \& Kiuchi, T. Increase in Memory (CD4+CD29+ and CD4+CD45RO+) $\mathrm{T}$ and Naive (CD4+CD45RA+)T-Cell

Subpopulations in Smokers. Archives of Environmental Health: An International Journal (1998). 53(6): 378-383.

[18] Tollerud, D.J.; Brown, L.M.; Blattner, W.A.; Mann, D.L.; Pankiw-Trost, L. \& Hoover, R.N. T Cell Subsets in Healthy Black Smokers and Nonsmokers: Evidence for Ethnic Group as an Important Response Modifier. American Review of Respiratory Disease Journals (1991). 144(3):1.

[19] Mi1ler, L.G.; Goldstein, G.; Murphy, M. \& Ginns, L.C. Reversible alterations in immunoregulatory $\mathrm{T}$ cells in smoking. Chest (1982). 82(5):526-29.

[20]Costa, C.; Rufino, R.; Traves, S. L.; Lapa, E.; Silva, J. R.; Barnes, P. J. \& Donnelly, L. E. CXCR3 and CCR5 chemokines in induced sputum from patients with COPD. Chest (2008). 133(1):26-33. [21] Liu, 21. Moszczynski, P.; Zabinski, Z.; Moszczynski, P.Jr.; Rutowski, J.; Slowinski, S. \& Tabarowski, Z. Immunological findings in cigarette smokers. Toxicology Letters (2001). 118(3):121-127. [22]Modestuo, M.A.; Manzel, L.J.; ElMahdy, S. \& Look, D.C. Inhibition of IFN- $\gamma-$ dependent antiviral airway epithelial defense by cigarette smoke. Respiratory Research (2010). 11:64.

[23] Benjamini, E.; Coico, R. \& Sunshine, G. ( 2000). Immunology Ashort Course, 4th ed - Wiley Liss . Canada [24] Abbas, A.K.; Lichtman, A.H. \& Pillai, S. (2010). Cellular and Molecular Immunology. 6th ed. philadelphia: Elsevier United states . pp: 6,18,267, 545 . 